\title{
GEOPHYSICAL MAPPING OF MAJOR STRUCTURES OF SOUTHERN AFRICA AND AN ASSESSMENT OF KIMBERLITE CORRELATION
}

\author{
Branko Corner \\ Mineral Services, Cape Town, South Africa
}

\section{INTRODUCTION}

A number of studies have been conducted with regard to the tectonic controls and the role of crustal scale fracture zones on kimberlite location (e.g. Helmstaedt and Gurney 1995; Dawson, 1970; White et al., 1995; Vearncombe and Vearncombe, 2002). Southern African studies have, however, lacked the detailed mapping, using potential field data combined with mapped geology, that is essential for a full analysis in this regard. This shortcoming in part results from the lack of merged aeromagnetic and gravity data sets covering the subcontinent at the highest possible resolution.

The present study aims at providing a unified regional structural interpretation of sub-equatorial Africa, using merged data sets, as a basis for assessing the correlation of kimberlite location with structure. The structural interpretation is based on the integration, refinement and extension of past interpretations of geophysical and geological data sets by the author, covering portions of southern Africa, including the Kaapvaal craton (Corner, 1991, 1998 and 2002a; Corner et al., 1986) and Namibia (Corner, 2000; Corner et al., 2002). These past studies were not specifically focused on kimberlites. The present study combines for the first time this integrated structural interpretation with the locations of southern Africa kimberlites (Figure 1).

\section{DATA SETS AND INTERPRETATION}

Merged aeromagnetic, gravity and geological data covering portions of sub-equatorial Africa, were used in the compilation of the regional structural interpretation presented here. No data were available for Angola or Zaire. The following data sets and transformations thereof were used during the course of interpretation: total magnetic intensity (TMI, merged at a $500 \mathrm{~m}$ grid interval for the entire sub-equatorial region), first vertical derivative of the TMI, reduced-tothe-pole TMI, modified analytical signal (to include long wavelength anomalies related to deeper sources), Bouguer gravity (also merged for the sub-equatorial region), first vertical derivative of the Bouguer gravity, and residual TMI and Bouguer gravity, based on spectral analysis and the application of a Gaussian filter. Realtime apparent sun-shading of the above data sets greatly facilitated identification of structures and structural trends.

In this presentation, mapped structures are simplistically classified into three geophysically observable types (Figure 1), i.e. major faults; lineaments, including larger continental scale lineament zones; and ring structures. The major faults shown are either taken from regional geological maps or are interpreted from the geophysical data. Given the coarse resolution of the geophysical data the faults may not necessarily be continuous singular features on the ground but rather comprise local fault zones. The interpreted lineaments and larger continental scale lineament zones, schematically shown as lines in Figure 1, are much broader semi-linear swaths encompassing an array of parallel or sub-parallel structures, as well as possible intrusions. The swaths may be as wide as $100 \mathrm{~km}$ and reflect deformation and anomalous sources in a range of depths from surface to $3 \mathrm{~km}$ or more depending on the size of the causative feature and its physical property contrast. The current and past interpretations (Corner, 2002a) also identify numerous arcuate or circular fault systems, here termed ring structures. Figure 1 includes ring structures which are semi-regional or cratonic scale in extent. These are discussed more fully below.

The structures shown in Figure 1 are thus not broadbrush features. They are based on detailed mapping of faults, trends, and alignment of intrusions, which themselves cannot necessarily all be shown on a simplified map. Neither age relationships nor structural styles (e.g. lystric, thrust, strike-slip faults) are suggested for any of the structural features shown in this presentation. Similarly, the kimberlite distribution shown here does not distinguish age, group, diamond content, or associated alkaline or phonolitic intrusions. These aspects form an important component of ongoing studies.

\section{DISCUSSION}

\section{Lineaments and faults}

Corner (2002a and 2000) and Corner et al. (2002) discuss the nature and manifestation of the major 
lineaments shown in Figure 1. A number of structural directions are evident, e.g. the

- north-northwest trending Khoisan and Bethlehem Lineaments;

- $\quad$ north-south trending Kalahari, Colesberg and Strydenburg (north) Lineaments;

- $\quad$ north-northeast trend exemplified by the often contested alignment of the Trompsburg and Bushveld Complexes, the Vredefort structure and the Great Dyke, continuing into the Tanzanian craton; this direction is also a common late Damaran trend in Namibia, e.g. the Kudu Lineament; the trend is referred to as the "Great Dyke" lineament for the purposes of discussion in this text;

- $\quad$ northeast trending Omaruru Lineament Zone (OMLZ), Opuwo Lineament, and Transsouthern African Lineament Zone (TSALZ);

- east-northeast trending Kimberley-Barberton, Thabazimbi-Murchison, Zoetfontein and Lurio (west extension) Lineaments.

Numerous smaller scale faults parallel these features, only a few of which have been shown in the simplified version of the interpretation presented in Figure 1. The above directions are consistent with those derived by Vearncombe and Vearncombe (2002). In their study, they have applied a geometric method of spatial analysis to demonstrate that kimberlite location is controlled by fundamental crustal fractures including Archaean and Proterozoic directions, and offshore Phanerozoic fracture zones. The present study also fully supports these ages of the fracture systems.

An important conclusion from the study of Corner et al. (2002) is that structures that have always been assumed to be specifically pan-African or Kibaran in age clearly have been active in the Phanerozoic, and even in recent times. This is evidenced, for example, in the Namibian offshore magnetic, gravity and seismic data (Corner et al., 2002) where the pan-African OMLZ, a major continental scale structure, is seen in the shiptrack data to continue offshore Namibia as the Walvis Fracture Zone (WFZ). This phenomenon is interpreted to arise from the likelihood that the OMLZ constituted a favourable direction at the time of breakup, initiating the WFZ. The latter reactivated the OMLZ as recently as the Cretaceous, as is evidenced in part by the Waterberg thrust fault along which Damaran rocks are thrust onto Karoo strata. A similar origin is interpreted for the TSALZ, a major feature evident in the magnetic data, which has also been identified in other studies (e.g. Sahu, 2000). Similarly, the Kibaran Pofadder Lineament (Pofadder-Tantalite valley shear) is seen to continue offshore Namibia in the potential field and seismic data, controlling the disposition of basalt extrusion after breakup (Corner, et al., 2002). Thus faults and fault zones should be assigned activation age limits, rather than a singular age.

\section{Ring structures}

The mapping of ring structures is relatively uncommon in local literature, other than in studies focused specifically on meteorite impact and more rarely on crypto-explosions. Yet hese features, in a thorough analysis of potential field data, are readily evident. Ring structures observed on a local scale in high resolution data sets are almost always associated with centrally located intrusions, e.g. granitic plutons, deep seated batholiths, or plug like intrusions such as carbonatites and phonolites (Corner, 2002a). Manifestations of fluid movement along the arcuate fractures are frequently evidenced in the radiometric data. In this respect there is scope for analysis of high resolution data covering kimberlite fields to investigate whether ring fracture systems may be commonly associated with them. Origins of the semi-regional features shown include possible meteorite impact sources (e.g. Vredefort and Morokweng, Figure 1), or major intrusive sources, (e.g. Nama ring structure, Corner, 2002b). The craton-scale ring structures mapped (i.e. the Kaapvaal and Zimbabwe ring structures, KVRS and ZRS respectively, Figure 1) may be related to craton rotation, craton margin deformation during the evolution of the surrounding polymetamorphic terranes, or to mantle processes. To have remained clearly in evidence, a ring structure would have to be late- to post-tectonic. They may, however, be older features which have been reactivated, as in he case of major fault zones as discussed above.

\section{Kimberlite location: correlation with structure}

Correlations between kimberlite location and structure, seen both regionally and locally for most of the kimberlite fields shown in Figure 1, are enumerated below. For the sake of simplicity of discussion kimberlite clusters or fields will be referred to using the name of the most prominent kimberlite in each area, as shown on Figure 1.

i) The well known Orapa-Gope-Kokong-TsabongGamoep corridor clearly parallels the TSALZ, and is manifested along part of its length from Orapa to Kokong by a lineament evident in the gravity data. This lineament is parallel to the TSALZ, but offset $150-200 \mathrm{~km}$ to the east. It was thus a more favourable zone of extension than the TSALZ itself, favouring 
kimberlite emplacement. The corridor of Angolan kimberlites has a similar orientation and may also be associated with the continental manifestation of an offshore Phanerozoic fracture zone.

ii) The kimberlite fields in the Kimberley area, extending southward to the Kaapvaal craton boundary and beyond, show a striking confinement between the Colesberg Lineament (CL, Figure 1) and the Kheis Lineament (KL, Figure 1; a major thrust margin). These structures are assumed to be Archaean to palaeoProterozoic at their oldest manifestation. This large kimberlite field is also constrained in the north by the Trans-Kalahari Lineament (TKL, Figure 1), but this may be more apparent than real being a possible consequence of the increased Kalahari cover to the north. The off-craton extension of the kimberlite field southward follows the mapped Strydenburg Lineament, (SL, Figure 1) evidenced in both the magnetic and gravity data.

iii) A further striking correlation of the kimberlite field in the Kimberley area is that the highest frequency of kimberlites forms a roughly northwest trending belt from Jagersfontein (just northwest of the Trompsburg Complex, TC, Figure 1), through the Koffiefontein area to Kimberley. This belt is parallel to and bounded in the east by the Khoisan Lineament. Within this belt, the greatest cluster of kimberlites occurs at the intersection of the Khoisan Lineament and KimberleyBarberton Lineament (KBL, Figure 1).

iv) Although the origin of the Kaapvaal ring structure (KVRS, Figure 1) is poorly understood at this stage it is possibly related to Kibaran age deformation as its southern lobe constitutes the Namaqua-Natal Front. The Premier, Jwaneng and Tsabong kimberlite fields all lie on the KVRS at its intersection with the other mapped lineaments shown, mostly derived from the gravity data.

v) Extension zones, hallmarked by dykes and dyke swarms host kimberlite fields, particularly at their intersection with major cross cutting faults and lineaments. The River Ranch, Venetia, Martins Drift, Trillion, Orapa, Sikereti kimberlites or kimberlite fields all lie within the main limits of the Botswana dyke swarm. The zone of northwest trending dykes and faults central to the Zimbabwe craton are also host to kimberlite fie lds.

vi) Further examples of the observations of points iii, iv and $\mathrm{v}$ above, that a number of kimberlite fields correlate with fault zone and broader structural lineament intersections, include, e.g. Orapa (southwest extension of the Lurio Lineament intersecting with a gravity lineament within the Botswana dyke swarm), Kokong (intersection of two gravity lineaments with the Zoetfontein fault zone and other smaller scale faults). Fault and fracture intersections clearly provide the pathways for kimberlitic fluids. The studies of Basson et al. (2002) on fluid extraction through plate velocity changes during the Cretaceous are of interest in this regard.

vii) The Tanzanian kimberlites display a prominent north-south trend coinciding regionally with the northward extension of the "Great Dyke" lineament, at its intersection with a major set of northeast faults.

This lineament and the kimberlite field also parallels a dyke swarm to the west.

ix) The Letseng kimberlite field strikes northwest, sub-parallel to the Bethlehem lineament.

\section{CONCLUSIONS}

This study shows that there is a clear correlation between major lineaments and kimberlite location, the latter either being constrained by them, parallel to them, or occurring at their intersections. Lineaments interpreted to be continental manifestations of offshore fracture zones are important to kimberlite location, but older lineaments also show correlation. Lineaments mapped from gravity data appear to hold a closer relationship to the location of kimberlite fields. Extension zones, hallmarked by dykes, host kimberlite fields particularly at their intersection with major cross cutting faults and lineaments. At least three major kimberlite fields lie on the Kaapvaal ring structure, at its intersection with other lineaments and faults.

This study demonstrates the importance of regional structure on kimberlite location, with major implications for the definition of prospective ground. Future research should be directed to refining the detail of the structural interpretation, as well as at studying the correlation with subsets of kimberlite data, including group type, diamond content, petrography, related intrusions and age.

\section{REFERENCES}

Basson, I.J., Jelsma, H. and Viola, G., 2002. Rapid kimberlitic fluid extraction from the mantle lithosphere. Proc. $11^{\text {th }}$ IAGOD Quadrennial Symposium and Geocongress, Windhoek, Namibia, Geol. Surv. Namibia. 
Corner, B., 2002a. Ring structures of southern Africa. Proc. $11^{\text {th }}$ IAGOD Quadrennial Symposium and Geocongress, Windhoek, Namibia, Geol. Surv. Namibia.

Corner, B., 2002b. Structural mapping of Namibia derived from interpretation of geophysical and geological data. Poster. Proc. $11^{\text {th }}$ IAGOD Quadrennial Symposium and Geocongress, Windhoek, Namibia, Geol. Surv. Namibia.

Corner, B., Cartwright, J., and Swart, R., 2002. Volcanic passive margin of Namibia: A potential fields perspective. In: Menzies, M.A., et al. (Eds.), Volcanic Rifted margins. Geological Society of America, Spec. Paper 362, 207-224.

Corner, B., 2000. Crustal framework of Namibia derived from magnetic and gravity data. Communs. geol. Surv. Namibia 12, 13-19.

Corner, B., 1998. A geophysical perspective of the Kaapvaal Province. Southern African Geophysical Review, 2, 19-28.

Corner, B., 1991. Crustal architecture of the Precambrian of the Kaapvaal Province from geophysical data. Proc. Precambrian Sedimentary basins of southern Africa, Terra Abstracts Supp. 3 to Terra Nova, 3, pp. 5.

Corner, B., Durrheim, R.J. and Nicolaysen, L.O., 1986. The structural framework of the Witwatersrand basin as revealed by gravity and aeromagnetic data. Proc. Geocongress 86, Johannesburg, South Africa, p 27-30.

Dawson, J.B., 1970. The structural setting of African kimberlite magmatism. In: Clifford, TN., Gass, I.G.
(Eds.), African Magmatism and tectonics. Hafner Publishing Co., pp. 321-335.

Helmstaedt, H.H. and Gurney, J.J., 1995. Geotectonic controls of primary diamond deposits: implications for area selection. Journal of Geochemical Exploration, 53, 125-144.

Sahu, B.K., 2000. Aeromagnetics of selected continental areas flanking the Indian Ocean; with implications for geological correlation and reassembly of central Gondwana Ph.D. Thesis, University of Cape Town, South Africa.

Vearncombe, S. and Vearncombe, J.R., 2002. Tectonic controls on kimberlite location, southern Africa. Journal of Structural Geology, 24, 1619-1625.

White, S.H., Boorder, H., Smith, C.B., 1995. Structural controls of kimberlite and lamproite emplacement. Journal of Geochemical Exploration, 53, 245-264. 


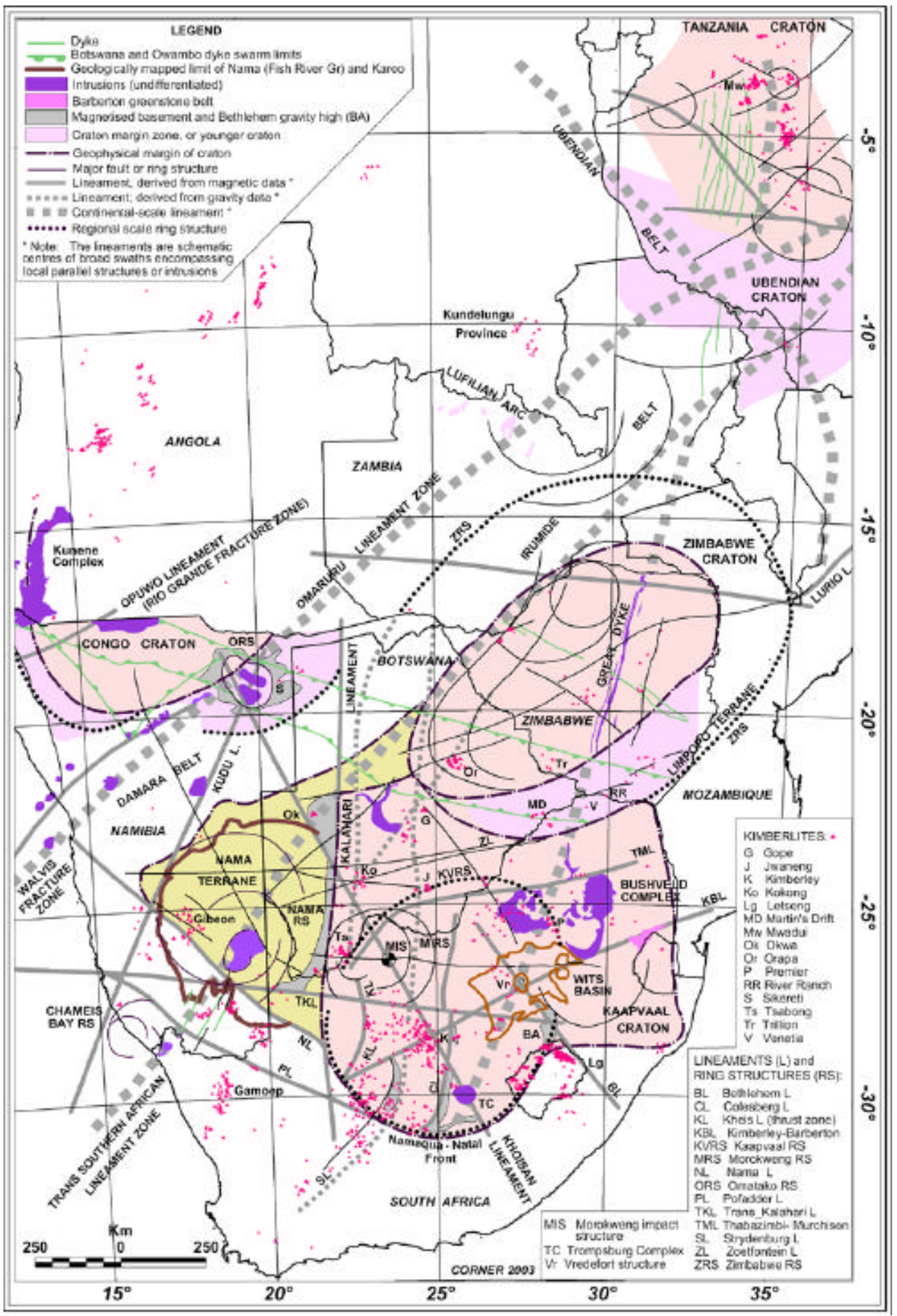

Figure 1. Simplified geophysically-derived structure of southern Africa showing kimberlite locations. 